Michał Zmuda

\title{
Główne wyznaczniki metodologii canonical approach według Brevarda S. Childsa
}

Celem artykułu jest opis głównych założeń metodologicznych podejścia kanonicznego w ujęciu B. S. Childsa ${ }^{1}$, niedawno zmarłego amerykańskiego biblisty, byłego profesora Divinity School na Yale University w New Haven.

\section{Kontekst powstania nowego podejścia}

Powstałe przed ponad 30 laty w Ameryce canonical approach od początku było szeroko komentowane w środowiskach biblistów amerykańskich i niemieckich. B. S. Childs w swych kolejnych publikacjach stopniowo doprecyzowywał postulaty metodologiczne tworzonego podejścia, czego zwieńczeniem była książka Biblical Theology of The Old and New Testaments wydana w 1992 roku i zawierająca propozycję teologii biblijnej w kontekście kanonicznym, w odniesieniu do całej Biblii². Podejście kanoniczne zostało

\footnotetext{
${ }^{1}$ Stosowana przeze mnie w artykule nazwa „podejście kanoniczne” pochodzi z dokumentu Papieskiej Komisji Biblijnej pt. Interpretacja Biblii w Kościele. W języku francuskim, oryginalnym języku dokumentu, użyto słowa approche, które można tłumaczyć jako „podejście” lub „ujęcie”. Również angielskie wyrażenie canonical approach, które na określenie swej metodologii stosuje B. S. Childs, można przetłumaczyć jako „podejście kanoniczne”. Por. Papieska Komisja Biblijna, Interpretacja Biblii w Kościele, [w:] Interpretacja Biblii w Kościele. Dokument Papieskiej Komisji Biblijnej z komentarzem biblistów polskich, tłum. R. Rubinkiewicz, Warszawa 1999, s. 4042; B. S. Childs, Introduction to the Old Testament as Scripture, London 1979, s. 82. Canonical approach (podejście kanoniczne) należy odróżnić od canonical criticism (krytyki kanonicznej), drugiego nurtu w ramach tzw. egzegezy kanonicznej stworzonego przez Jamesa A. Sandersa. Obydwa sposoby interpretacyjne, mimo że Dokument Papieskiej Komisji Biblijnej wymienia je łącznie jako „podejście kanoniczne”, różnią się między sobą w kilku zasadniczych kwestiach. Niestety forma artykułu nie pozwala mi na szersze potraktowanie tej kwestii, dlatego też zaznaczam, że przedmiotem opisu będzie jedynie podejście kanoniczne według B. S. Childsa.

${ }^{2}$ Tak uważają m.in. A. Sanecki, Canonical approach. Propozycja interpretacji biblijnej wedtug Brevarda Springa Childsa, „Rocznik Seminaryjny Stadniki” 4 (2004/2005), s. 157; tenże, Approccio canonico: tra storia e teologia, alla ricerca di un nuovo paradigma post-critico. L'analisi della metodologia canonica di B. S. Childs dal punto di vista cattolico, Roma 2004, s. 105 (Tesi Gregoriana. Serie Teologia, 104); S. Szymik, Podejście kanoniczne w interpretacji Pisma Świętego, „Roczniki Teologiczne” 1 (2002) t. 49, s. 16-17.
} 
również wymienione przez dokument Papieskiej Komisji Biblijnej Interpretacja Biblii w Kościele w gronie nowych podejść interpretacyjnych opartych na tradycji ${ }^{3}$. Wydaje się więc, że kanoniczny sposób interpretacji wpłynął na aktywność wielu uczonych ${ }^{4}$ i już na stałe wszedł do egzegezy biblijnej. Mimo to w Polsce w dalszym ciągu jest praktycznie nieznany. Tym większa istnieje zatem potrzeba, aby przynajmniej pokrótce przybliżyć polskiemu czytelnikowi jego podstawowe założenia.

Podejście kanoniczne pojawiło się w momencie, gdy w biblistyce od przeszło 150 lat dominowała metoda historyczno-krytyczna, która uchodziła za jedyny naukowy sposób badania Biblii. Propozycja B. S. Childsa była w głównej mierze spowodowana konkluzją o nieadekwatności, a tym samym niewystarczalności metody historyczno-krytycznej w interpretacji Biblii jako Pisma Kościoła ${ }^{5}$. Chodziło w znacznej mierze o przesadne „poszatkowanie” Pisma Świętego zarówno w wymiarze horyzontalnym (podział na poszczególne księgi i ich części, które mają prezentować odrębną teologię), jak i wertykalnym (rozbicie tekstu na warstwy, pre-teksty i redakcje). Pracę nad nowym podejściem egzegetycznym amerykański biblista rozpoczął od stwierdzenia, że metoda historyczno-krytyczna nie zgłębia teologicznego wymiaru Biblii w stopniu odpowiednim do charakteru tego tekstu. Z tego też powodu uniemożliwia skuteczne aktualizowanie ${ }^{6}$ orędzia słowa Bożego dla dzisiejszych pokoleń wierzących. Aby aktualizacja była możliwa i żeby sprowadzić Pismo Święte z „uniwersytetu do Kościoła”, amerykański uczony zaproponował nową perspektywę hermeneutyczną,

${ }^{3}$ Por. Papieska Komisja Biblijna, Interpretacja Biblii w Kościele, dz. cyt., s. 40-42.

${ }^{4}$ Tzw. „egzegezę kanoniczną” wymienia i przyznaje się do jej stosowania papież Benedykt XVI w swojej ostatniej książce Jezus z Nazaretu. Ponadto, jak podaje ks. A. Sanecki, do takiego wpływu przyznawał się otwarcie znany teolog biblijny Rolf Rendtorff; por. Benedykt XVI, Jezus z Nazaretu, cz. 1, thum. W. Szymona OP, Kraków 2007, s. 10nn; A. Sanecki, Problem kanonu biblijnego we wspótczesnej interpretacji Pisma świętego, „Rocznik Seminaryjny Stadniki” 3 (2003/2004), s. 151.

${ }^{5} \mathrm{O}$ konieczności dopełnienia metody historyczno-krytycznej przez inne kroki badawcze bibliści przekonywali się coraz bardziej. Nie pozostawia co do tego wątpliwości także dokument Interpretacja Biblii w Kościele, który stwierdza wprost, że żadna metoda nie jest w stanie ująć całego bogactwa tekstu biblijnego. Dokument podkreśla, że nowe sposoby badania Pisma Świętego ubogacają rezultaty metody historyczno-krytycznej, a zarazem są reakcją na jej ograniczenia; por. Papieska Komisja Biblijna, Interpretacja Biblii w Kościele, dz. cyt., s. 32.

${ }^{6}$ Aktualizacja według dokumentu Interpretacja Biblii w Kościele jest wysiłkiem teologów zmierzającym do właściwego odniesienia przesłania tekstu biblijnego do nowej sytuacji współczesnych wierzących. Papieska Komisja Biblijna zasady i metody aktualizacji omawia w czwartej, ostatniej części dokumentu; por. Papieska Komisja Biblijna, Interpretacja Biblii $w$ Kościele, dz. cyt., s. 88-92. Zagadnienie aktualizacji szczegółowo omawia również ks. Roman Pindel; por. tenże, Aktualizacja wedtug Dokumentu Papieskiej Komisji Biblijnej „Interpretacja Biblii w Kościele”, [w:] Z badań nad Biblia, t. 5, Kraków 2002, s. 9-26. 
której fundamentem było uwzględnienie fenomenu kanonu biblijnego jako zasady, normy i kontekstu w egzegezie ${ }^{7}$. Stąd też nazwa całego systemu - podejście kanoniczne (canonical approach).

Podstawowe założenia podejścia kanonicznego można więc rozumieć dwojako: od strony negatywnej jako krytykę ekskluzywizmu metod krytycznych oraz od strony pozytywnej jako propozycję koniecznych norm we właściwej interpretacji Pisma Świętego ${ }^{8}$. Podczas opisu podstawowych postulatów metodologicznych canonical approach, postaram się wydobyć oba te wymiary.

\section{Interpretacja w wierze}

Podstawowym problemem dla B. S. Childsa sygnalizowanym już od najwcześniejszych jego artykułów dotyczących podejścia kanonicznego są złe założenia przyjmowane w egzegezie przez metody krytyczne, a zwłaszcza postulat o neutralności badacza wobec opisywanego tekstu. Zadanie egzegety, według rozumienia tradycyjnego, to czynność dwojakiego rodzaju: pierwszy etap, neutralny i opisowy, to krytyka literacka i historyczna tekstu (descriptive task), etap drugi polega na wydobyciu i opisaniu problematyki teologicznej analizowanego tekstu (theological task $)^{9}$. Według naszego autora podstawowy błąd metod krytycznych leży w podejściu do pierwszego etapu, gdyż analizując tekst z pozycji „naukowej neutralności”10, traktuje go jako „źródło”, a nie jako „świadectwo”. Naturalnie, Biblia jest „źródłem” wiadomości o obyczajach, warunkach kulturowych i historycznych pomagającym zrozumieć początki Kościoła czy też świat starożytny. Jednak tekst biblijny jest przede wszystkim świadectwem wiary, zapisem spotkania Izraela i Kościoła z Bogiem. Ten wymiar znacznie przekracza historyczną naturę tekstu biblijnego. Co więcej, poprawne jego zrozumienie może być dokonane jedynie z perspektywy wiary. Dlatego według B. S. Childsa same analizy literacko-historyczne

\footnotetext{
${ }^{7}$ Por. A. Sanecki, Canonical approach..., dz. cyt., s. 156.

${ }^{8}$ Por. S. Szymik, Podejście kanoniczne..., dz. cyt., s. 16.

${ }^{9}$ Por. B. S. Childs, Interpretation in Faith. The Theological Responsibility of an Old Testament Commentary, „Interpretation. A Journal of Bible and Theology” 18 (1964), s. 437-438.

${ }^{10}$ B. S. Childs nie zgadza się ze stwierdzeniem, że tylko taka analiza jest naukowa, a przeciwstawienie obiektywnej naukowości subiektywnym założeniom uważa za bardzo niebezpieczne w egzegezie; por. tenże, Some reflections on the search for a biblical theology, „Horizons in Biblical Theology” 4/1 (1982), s. 5-6. Podobnie uważa ks. S. Szymik: „nie da się pominąć i nie można uznać za nienaukowe uzupełnienie badań biblijnych o wymiar wiary, prowadzenie badań biblijnych w duchu żywej wiary" (Podejście kanoniczne..., dz. cyt., s. 21).
} 
dokonywane z pozycji czysto neutralnej nie prowadzą do poprawnego odczytania (w wierze) sensu świadectwa Bibliii ${ }^{11}$.

Podejście kanoniczne od początku zostało tak pomyślane, aby traktować tekst biblijny jako świadectwo wiary i nie zatrzymywać się jedynie na korzystaniu z niego jako źródła historycznego. Biblia została bowiem napisana przez wierzących dla wierzących $\mathrm{i}$ jest przede wszystkim zapisem wejścia Boga w historię, które powoduje, że sama biblijna historia staje się wyjątkowa. Co więcej, podstawą autorytetu ksiąg Pisma Świętego wewnątrz wspólnoty, która je przechowywała, była wiara w ich Boże natchnienie. Zarówno wspólnota historycznego Izraela, jak i pierwotny Kościół, cenili swe święte księgi nie z powodu zawartych w nich interesujących danych historycznych czy socjologicznych, lecz z powodu treści teologicznych, które mówiły o Bożym objawieniu, a w przypadku Kościoła o objawieniu Boga w Jezusie Chrystusie. Dlatego też ta sama perspektywa wiary powinna towarzyszyć egzegecie od początku do końca, jeśli chce on badać teksty biblijne w sposób przystający do ich natury, czyli nie tylko jako „źródło” historyczne, ale jako „świadectwo” wiary, w którym lud Boży szuka objawiającego się Boga.

Podejście kanoniczne identyfikuje się więc z oceną pierwszych chrześcijan wobec Biblii ${ }^{12}$. Jest to równoznaczne z przyjęciem fenomenu unikalności kanonu i jego prerogatywy w egzegezie.

\section{Pojęcie kanonu i formy finalnej}

Przejdę teraz do bardziej szczegółowego opisu treści, jakie w propozycji B. S. Childsa kryją się pod pojęciem kanonu. Zostało ono sformułowane w specyficzny sposób, a jego zrozumienie jest swoistym kluczem do interpretacji całego opisywanego systemu. Kanon w metodologii canonical approach ma trzy podstawowe znaczenia.

W pierwszym znaczeniu kanon oznacza po prostu zbiór ksiąg uznawanych przez Kościół za natchnione i używanych jako takie w liturgii, w przepowiadaniu i w modlitwie. Kolekcja Pism ma charakter normatywny; jest podstawową materią i zarazem granicą egzegezy chrześcijańskiej. W tym sensie kanon funkcjonuje jako norma interpretacyjna w rodzaju reguły wiary ${ }^{13}$.

${ }^{11}$ Por. B. S. Childs, Interpretation in Faith..., dz. cyt., s. 437-438, 445; tenże, The Book of Exodus: a Critical, Theological Commentary, Louisville 1974, s. XIII; tenże, The New Testament as Canon. An Introduction, London 1984, s. 38-39. Podobny pogląd wyraża m.in. ks. T. Jelonek, Biblijna historia zbawienia, Kraków 2004, s. 15-17.

${ }^{12}$ B. S. Childs, The New Testament as Canon..., dz. cyt., s. 43.

${ }^{13}$ Por. A. Sanecki, Canonical approach..., dz. cyt., s. 159. Autor stwierdza ponadto, że B. S. Childs w miejsce reguły wiary kojarzonej z tradycją katolicką pragnie wprowadzić inną 
Kanon w drugim znaczeniu stanowi historyczny i literacki proces, który miał miejsce we wspólnocie wiary. Uformowanie się kanonu w ramach procesu kanonicznego jest pochodną wzajemnego oddziaływania na siebie tekstu i wspólnoty wiary. Tekst nadał wspólnocie formę, a wspólnota ukształtowała tekst. Proces kanoniczny należy odróżnić od historii formowania się literatury biblijnej. Jego charakter jest ściśle teologiczny, chociaż rozwijał się w historii. Na każdym etapie procesu nowe zrozumienie (przeformułowanie) Pism było wynikiem „objawiania się” Boga i Jego doświadczenia przez wspólnotę ${ }^{14}$. Proces kanoniczny jest więc serią natchnionych decyzji i działań w ramach kolejnych tradycji wewnątrz wspólnoty wiary, mających głęboki wpływ na kształt samych Pism, aż do ich kanonizacji (uformowania się kanonu) ${ }^{15}$. Proces kanoniczny nie był przypadkowy. Kierowała nim motywacja teologiczna (intencja kanoniczna) ze strony wspólnoty wiary, a mianowicie: dostosowanie przesłania Biblii do odczytania go przez każde następne pokolenie wierzących. Intencja kanoniczna pozostawiła swoje znaczące ślady w tekście kanonicznym. Jednym z głównych zadań egzegety jest więc zrozumienie sposobu formowania się tekstu biblijnego w procesie kanonicznym - selekcji, zebrania i uporządkowania materiału - co ma mu pomóc we właściwej interpretacji tego tekstu ${ }^{16}$.

zasadę, bardziej biblijną - regułę kanonu.

${ }^{14}$ Według B. S. Childsa niedocenianie roli kanonu w egzegezie wiąże się ze złym zrozumieniem natury tego procesu, np. część egzegetów uważa ukonstytuowanie się kanonu jako wynik narzuconej z zewnątrz oceny ksiąg późniejszej niż sam tekst biblijny, dokonanej przez wspólnotę Izraela lub Kościół. Nie można jednak kanonu utożsamić z tradycją „,zamrożoną w czasie", czyli w szczególnym kontekście, w którym miała ona znaczenie jako norma, a która w dzisiejszym kontekście takiego znaczenia już nie ma. To dziedzictwo wiary, a nie rozumu ustanawia kanon, jednak w tym ustanowieniu widoczna jest pewna logika wiary (cel teologiczny) - por. B. S. Childs, Response to reviewers of Introduction to the OT as scripture, „Journal for the Study of the Old Testament” 16 (1980), s. 56; tenże, Introduction to the Old Testament..., dz. cyt., s. 59.

${ }^{15}$ Podejście kanoniczne nie przyznaje wartości tekstom biblijnym według jakiegoś zrekonstruowanego hipotetycznie „kanonu w kanonie” czy innego zewnętrznego kryterium (np. ponadczasowych prawd filozoficznych, poszukiwań tożsamości przez wspólnotę). Uznaje je a priori (według założeń wiary) w całości za przekazane i utrwalone w procesie kanonicznym i dlatego autorytatywne - por. S. Szymik, Podejście kanoniczne..., dz. cyt., s. 23; B. S. Childs, The Exegetical Significance of the Canon for the Study of the Old Testament, „Supplements to Vetus Testamentum" 29 (1978), s. 67.

${ }^{16}$ Istotny jest już sam fakt ułożenia ksiąg wewnątrz kanonu. Np. kanon hebrajski jest skoncentrowany wokół Tory, lecz LXX i kanon chrześcijański Starego Testamentu kończą się zbiorem proroków, a tym samym zostaje otwarta „droga” na wypełnienie się proroctw w Chrystusie. Podobnie Księga Powtórzonego Prawa pochodząca z okresu późnej monarchii w historii Izraela otrzymała szczególną funkcję w obrębie kanonu - jest interpretacją Prawa przez swoją strukturę i pozycję w Pięcioksięgu. Ewangelia według św. Łukasza pierwotnie 
Trzeci aspekt pojęcia kanonu, obecny w metodologii B. S. Childsa, to aktywność interpretacyjna współczesnego czytelnika Biblii. Zmierza ona nie tylko do przyjęcia w całości zachowanego depozytu tradycji, ale przede wszystkim do właściwego odczytywania (aktualizacji) i przekazywania przesłania Biblii w dzisiejszym świecie ${ }^{17}$. Postulat interpretacji w wierze zostaje w ten sposób usprawiedliwiony metodologicznie jako rodzaj swoistej kompetencji czytelnika w odczytaniu tekstu ${ }^{18}$.

Kanon w metodologii B. S. Childsa, stając się podstawową zasadą hermeneutyczną, wraca na centralne miejsce w interpretacji Biblii i powoduje szereg konsekwencji w uprawianiu nauk biblijnych. Jedną z nich jest wyakcentowanie formy finalnej tekstu biblijnego. Wartość przypisana tej formie to jedna $\mathrm{z}$ najbardziej rozpoznawalnych cech podejścia kanonicznego, odróżniających je od krytycznych metod interpretacyjnych.

Forma finalna (inaczej kanoniczna) jest, mówiąc najprościej, efektem zakończonego procesu kanonicznego. Jednak, jak powszechnie wiadomo, nie posiadamy dzisiaj dostępu do tekstów oryginalnych Pisma Świętego w ich formie finalnej, jak to definiuje canonical approach. Dlatego, według B. S. Childsa, należy posługiwać się krytyką tekstu, żeby ustalić najbardziej prawdopodobne brzmienie tekstu oryginalnego na podstawie dostępnych odpisów ze starożytności. Egzegeza teologiczna zaś powinna zająć się formą kanoniczną tekstu, którą aktualnie akceptuje i przechowuje Kościół. Równocześnie B. S. Childs jest świadom tego, że forma finalna nie jest monolitem, który zawsze ma jednoznaczny wydźwięk. Tekst, jako rezultat procesów historycznych, jest wielowarstwowy. Tego faktu nie można zlekceważyć, wręcz przeciwnie, należy go badać krytycznie. Jednak studium nad prehistorią ma właściwą funkcję, jeśli traktuje się je jako naświetlenie tekstu finalnego ${ }^{19}$.

\section{Kontekst kanoniczny i jedność Biblii.}

Kanon w pierwszym znaczeniu omawianym powyżej jest według B. S. Childsa najwłaściwszym kontekstem dla uprawiania egzegezy ${ }^{20}$ i zawiera złączona z Dziejami Apostolskimi w kanonie funkcjonuje oddzielnie, dlatego odtąd powinna być interpretowana łącznie z Ewangeliami.

${ }^{17}$ Zdaniem B. S. Childsa prawdziwa interpretacja tekstu zawiera się w interakcji pomiędzy czytelnikiem a tekstem. Lektura Pism jest źródłem wyznania wiary w tego samego Pana - Jezusa Chrystusa, o którego życiu, śmierci i zmartwychwstaniu świadczą teksty biblijne, w Ducha Świętego, przez którego otrzymujemy zbawienie i w Kościół, który o Nich przekazuje świadectwo - por. B. S. Childs, The New Testament as Canon..., dz. cyt., s. 40.

${ }^{18}$ Por. A. Sanecki, Approccio canonico..., dz. cyt., s. 130.

${ }^{19}$ Por. B. S. Childs, The Book of Exodus..., dz. cyt., s. XV; tenże Childs versus Barr, „Interpretation. A Journal of Bible and Theology" 38 (1984), s. 68-69.

${ }^{20}$ Por. B. S. Childs, Biblical Theology in Crisis, Philadelphia 1970, s. 99. 
w sobie relację między sensem pojedynczego tekstu a sensem całej Biblii. Tekst poprzez włączenie w kanon często otrzymuje nowy kontekst teologiczny (kanoniczny), a tym samym możliwa jest jego nowa interpretacja. W ten sposób intencja pierwotnego autora tekstu zostaje podporządkowana intencji kanonicznej (całości Biblii), co trzeba respektować w egzegezie ${ }^{21}$.

Podkreślenie wartości kontekstu kanonicznego wypływa, choć pośrednio, z przekonania B. S. Childsa o natchnieniu ksiąg ${ }^{22}$ i determinuje określone spojrzenie na całe Pismo Święte, które, mówiąc najogólniej, jest jednością opartą na kanonie, u którego podstaw leży natchnienie ksiąg. Dzięki istnieniu kontekstu kanonicznego relację między poszczególnymi świadectwami można scharakteryzować jako subtelną ,jedność w różnorodności”23. Postulat jedności Biblii, jako twierdzenie wypływające z wiary chrześcijańskiej, domaga się poważnego potraktowania w egzegezie, której celem powinno być zrozumienie i uargumentowanie tej jedności.

\section{„Trzecia droga” w egzegezie}

Ostatnią cechą szczególną podejścia kanonicznego, na którą należałoby zwrócić uwagę, jest specyficzne ustawienie relacji między historią a teologią świadectwa biblijnego, a ściślej rzecz biorąc, między jego wymiarem historycznym a wymiarem teologicznym. Od razu na początku warto podkreślić, że z pewnością nie można canonical approach określić mianem podejścia ahistorycznego. W zasadzie we wszystkich swych publikacjach B. S. Childs

${ }^{21}$ Podporządkowanie kontekstu pierwotnego kanonicznemu nie oznacza, że w egzegezie ten pierwszy należy pomijać lub odrzucać. Np. Pięcioksiąg mógł powstać z połączenia tradycji J, E, D i P, ale dopiero dzięki ostatecznej formie kanonicznej całości jesteśmy w stanie zrozumieć biblijną prehistorię zbawienia; Księga Izajasza składa się z trzech części pisanych w odstępie 250 lat, ale interpretacja całościowa jej formy finalnej usuwa różnorodność sytuacji życiowych utrwalonych w poszczególnych częściach; proroctwo z Księgi Amosa wygłoszone pierwotnie do konkretnej wspólnoty, umieszczone w szerszym kontekście teologicznym (kanonu) zyskuje nową interpretację eschatologiczną - por. B. S. Childs, The Canonical Shape of the Prophetic Literature, „Interpretation. A Journal of Bible and Theology” 32 (1978), s. 49-53; tenże, Introduction to the Old Testament..., dz. cyt., s. 76; tenże, Old Testament Theology in a Canonical Context, London 1985, s. 12-13; S. Szymik, Podejście kanoniczne..., dz. cyt., s. 20.

${ }^{22}$ Ten fakt zauważa wielu komentatorów podejścia kanonicznego - por. np. A. Sanecki, Canonical approach..., dz. cyt., s. 153; tenże, Approccio canonico..., dz. cyt., s. 122; P. R. Noble, Canonical approach. A critical Reconstruction of the Hermeneutics of Brevard S. Childs, Leiden 1995, s. 30-31 (Biblical Interpretation Series, 16).

${ }^{23}$ Natura jedności ksiąg świętych według canonical approach nie zawiera się tylko w ich kanoniczności. Na poziomie tekstu Biblii jest ona wprawdzie pochodną procesu kanonicznego, lecz na poziomie pozatekstowym gwarantuje ją boskie autorstwo i jeden Boży cel, na które wskazują kolejne biblijne świadectwa - por. B. S. Childs, Biblical Theology of the Old and New Testaments. Theological Reflection on the Christian Bible, London 1992, s. 725; A. Sanecki, Approccio canonico..., dz. cyt., s. 152. 
podkreślał, że nie chce zrezygnować czy odrzucić historycznego wymiaru świadectwa, a jedynie właściwie zrozumieć jego naturę ${ }^{24}$. Historia jest obecna w Piśmie Świętym i teologia tekstu zależy od niej. Jednak relacja między historią a teologią nie jest bezpośrednia ${ }^{25}$. W istocie wymiar historyczny służy jedynie jako podstawa do wyrażenia prawd teologicznych, dlatego historia zawsze powinna być podporządkowana teologii. Jest to zamierzone przez B. S. Childsa docenienie wymiaru teologicznego.

Takie założenie relacji między obydwoma wymiarami tekstu skutkuje również ograniczeniem wpływu wyników metody historyczno-krytycznej na interpretację Pisma Świętego. Mamy więc z jednej strony dowartościowanie tradycyjnej egzegezy przed-krytycznej, opartej na wierze, z drugiej zaś strony przekonanie, że nie można lekceważyć wyników badań krytycznych. Nie chodzi tu o próbę przywrócenia przed-oświeceniowego spojrzenia na Biblię, ale raczej o skonstruowanie nowego post-liberalnego, post-krytycznego $^{26}$. Ks. A. Sanecki nazywa takie podejście „trzecią drogą” w egzegezie, prowadzącą przez pomost zawieszony między historią a teologią, między interpretacją historyczno-krytyczną a teologiczną ${ }^{27}$.

\section{Zakończenie}

Przedstawione powyżej główne charakterystyki podejścia kanonicznego, w mojej ocenie, ukazuja je jako bardzo ciekawą propozycję w egzegezie. Jak się jednak wydaje, trudno podejście kanoniczne uznać za samodzielną metodę interpretacji. Jego podstawowe założenia dotyczą bardziej postaw badacza i określonego sposobu patrzenia na tekst niż konkretnego zestawu czynności

${ }^{24}$ Historia biblijna jest bowiem historią szczególną, posiadającą własną specyfikę i choć zawiera się w historii powszechnej, nie można jej z nią zrównać. Wydarzenia zbawcze opisane w Biblii nie są „czystymi” faktami historycznymi, ponieważ w procesie relektury i aktualizacji ulegały często reinterpretacji razem z tekstem biblijnym. Jeśli chce się dobrze zrozumieć przesłanie Pisma Świętego, nie można oddzielać wydarzeń historycznych od reszty świadectwa, jakie stanowi tekst biblijny - por. np. B. S. Childs, Interpretation in Faith, dz. cyt., s. 433; tenże, The Book of Exodus..., dz. cyt., s. XV; tenże, Introduction to the Old Testament..., dz. cyt., s. 71-76; tenże, The New Testament as Canon..., dz. cyt., s. 24; tenże, Biblical Theology..., dz. cyt., s. 719-720.

${ }^{25}$ Por. A. Sanecki, Approccio canonico..., dz. cyt., s. 141; P. R. Noble, Canonical approach..., dz. cyt., s. 59-60.

${ }^{26}$ Sam B. S. Childs widzi swoją propozycję jako postkrytyczną, szanującą wiarę wspólnoty i tradycję ponad siedemnastu wieków egzegezy przedkrytycznej uprawianej w Kościele, a z drugiej strony otwartą na osiągnięcia badań historyczno-krytycznych - por. B. S. Childs, Childs versus Barr, dz. cyt., s. 69.

${ }^{27}$ Por. A. Sanecki, Approccio canonico..., dz. cyt., s. 142. 
badawczych ${ }^{28}$. Czy takie wskazówki są w ogóle potrzebne i przydatne? Co wnoszą do egzegezy? Odpowiedź na te pytania nie jest prosta, gdyż wymaga pogłębionego studium nad relacją wiary i rozumu w teologii, które wykracza poza ramy tego artykułu. Warto jednak zaznaczyć, że przedstawione postulaty canonical approach mają podstawowe znaczenie dla egzegezy teologicznej. Zauważa to również papież Benedykt XVI we wstępie do swej najnowszej książki Jezus $z$ Nazaretu: „W słowie wypowiedzianym w przeszłości dostrzegalne jest pytanie o jego «dzisiaj»; w słowie ludzkim pobrzmiewa coś większego; pojedyncze księgi w jakiś sposób wskazują na żywy proces powstającego w nich jednego Pisma. Właśnie to ostatnie spostrzeżenie zadecydowało o powstaniu przed około 30 laty w Ameryce «egzegezy kanonicznej», której celem jest czytanie pojedynczych tekstów w całości jednego Pisma, dzięki czemu wszystkie pojedyncze teksty ukazują się w nowym świetle. Ogłoszona przez Sobór Watykański II Konstytucja o Bożym Objawieniu w numerze 12 jednoznacznie już uznała to za podstawową zasadę teologicznej egzegezy: Kto chce zrozumieć Pismo w takim duchu, w jakim zostało napisane, musi brać pod uwagę treść i jedność całego Pisma. [...] Stanowi ona daną teologiczną, nie jest jednak po prostu od zewnątrz narzucona heterogenicznemu w sobie samym zbiorowi pism. [...] «Egzegeza kanoniczna»- czytanie pojedynczych tekstów Biblii w świetle ich całości - jest istotnym wymiarem interpretacji, który nie stoi w sprzeczności z metodą historyczno-krytyczną, lecz stanowi jej organiczną kontynuację i sprawia, że staje się ona teologią we właściwym tego słowa znaczeniu"29.

Podejście kanoniczne drogę do zaistnienia wśród innych rodzajów egzegezy torowało sobie przez wiele lat i spotkało się z różnymi ocenami: od bardzo pozytywnych po najbardziej krytyczne. B. S. Childs doczekał się nawet kilku uczniów, którzy podjęli i rozwinęli jego propozycję metodologiczną ${ }^{30}$. Z pewnością należy również podziwiać jego konsekwencję w budowie i w obronie swojego programu badawczego, zwłaszcza na

${ }^{28}$ Według założeń podejścia kanonicznego egzegeta może korzystać ze wszystkich innych metod i podejść w interpretacji Biblii, byleby respektował trzy zasadnicze kwestie: obowiązuje go stawianie teologii nad historią; interpretuje tekst kanoniczny i wydobywa jego sens kanoniczny; interpretacja dokonuje się we wspólnocie wiary i przy akceptacji przedzałożeń z tej wiary płynących. Wszystko, co pomaga w egzegezie, a nie sprzeciwia się tym podstawom, można w canonical approach zaadaptować.

${ }^{29}$ Benedykt XVI, Jezus z Nazaretu, dz. cyt., s. 10-11.

${ }^{30}$ Por. np. E. H. Dyck, Canon and Interpretation. Recent Canonical Approaches and the Book of Jonah. Ph. D. Dissertation, McGill University 1986; D. G. Hagstrom, The Coherence of the Book of Micah. A literary Analysis, Atlanta 1988 (Society of Biblical Literature. Dissertation series, 89); Ch. J. Scalise, From Scripture to Theology. A Canonical Journey into Hermeneutics, Downers Grove 1996; G. T. Sheppard, Wisdom as a Hermeneutical Context, New York 1980. 
początku ostro krytykowanego ze strony egzegetów posługujących się metodą historyczno-krytyczną. Świadomość braków powyższej metody i jej niewystarczalności w egzegezie, którą amerykański biblista miał już w latach 70. XX wieku, stopniowo dojrzewała także w Kościele katolickim i zaowocowała w 1993 roku dokumentem wydanym przez Papieską Komisję Biblijną, a ostatnio wypowiedziami papieża Benedykta XVI. Wypada więc mieć nadzieję, że i na gruncie polskim wartość canonical approach dla egzegezy nie pozostanie niezauważona.

Kraków

MICHAE ZMUDA

\section{Słowa kluczowe}

B. S. Childs, egzegeza, podejście kanoniczne, kanon biblijny, forma finalna

\section{Summary}

\section{Main methodological guidelines of the canonical approach according to Brevard S. Childs}

The article is a description of main methodological guidelines of the canonical approach according to Brevard S. Childs, a former professor and specialist of the Old Testament at Divinity School of Yale University (New Haven). This new interpretation of the Bible, brought forth by the Pontifical Biblical Commission in The Interpretation of the Bible in the Church has arisen as the basis of critique of several assumptions in regard to the historical critical method connected with the insufficient use of theological dimension of biblical texts in exegesis. Main methodological issues of canonical approach are characterized by the interpretation in faith; canon the as norm and border in explanation of biblical texts; emphasis on final form of canonical text; serious treatment of canonical context and unity of the Bible in exegesis. The fundamentals of canonical approach presented let us define it as a "third way" in exegesis, leading through bridge between history and theology.

\section{Keywords}

B. S. Childs, exegesis, canonical approach, biblical canon, final form 